Journal of Data Science 5(2007), 577-596

\title{
Impact of Foreign Direct Investment on Regional Innovation Capability: A Case of China
}

\author{
Yufen Chen \\ Zhejiang Gongshang University
}

\begin{abstract}
Foreign direct investment (FDI) has been traditionally considered an important channel in the diffusion of advanced technology. Whether it can promote technology progress for the host country is a focused problem. This paper analyzes the relationship between FDI and regional innovation capability (RIC). We find that the spillover effects of FDI are not as significant as it is usually thought. It is found that the impact of FDI on RIC is weak; the entry of FDI has no use for enhancing indigenous innovation capability. Moreover inward FDI might have the crowding-out effect on innovation and domestic R\&D activity. The research manifests that increasing domestic R\&D inputs, strengthening the innovation capabilities and absorptive capacity in domestic enterprises are determinants to improve RIC.
\end{abstract}

Key words: Foreign direct investment, principal component analysis, regional innovation capability, spillover effect, synthetic evaluation.

\section{Introduction and Summary}

Foreign direct investment (FDI) is a vital source for many less developed countries (LDCs) to obtain international capital and advanced technology. Chinese government attaches great importance to attracting FDI since the reformation and the "open-door" policy was carried in 1978. They implemented the "market for technology" policy and tried to facilitate technology progress through attracting inward FDI. China has received over 562.1 billions dollars before the end of 2004, and since 1993 China has been the largest FDI recipient among the LDCs. In 2004, the inward FDI reached 60.63 billions dollars. The ratio of FDI to GDP has surpassed 40 percent $^{1}$.

FDI is an important driving force to boost economic development in China. The impact of FDI has penetrated into many aspects of the national economy with the increase of total amount. The negative influence appeared gradually such as the homogeneous expansion of Chinese manufacturing and the international trade

\footnotetext{
${ }^{1}$ Gong, W. (2005). Having utilized foreign investments 562.1 billions dollars, experts said that this would not endanger our economic safety, People's Daily, 28 Jan.
} 
dissension because of the excessive reliance of FDI and FDI technology. Some issues remain to be addressed, for example, the strategic effect of the "market for technology" policy, the impact of FDI on technology progress in local firms.

The term spillover refers to the indirect effects generated by the presence of foreign firms both in the industrial structure of the host country and in the conduct and performance of local firms. There are a number of spillover effects of FDI identified in the literature (Caves, 1974; Globerman, 1979; Nadiri, 1993; Imbriani and Reganati, 1997). In particular, it is argued that the productivity of local firms may be mainly stimulated by three factors such as an increasing competition, the enhancing of human capital and the diffusion of new technologies. FDI was important to facilitate economic development and technology progress (Blomstrom and Persson, 1983; Blomstrom and Wolff, 1989; Kokko, 1994; Kokko et al., 1996; Borensztein et al., 1998; Sjoholm, 1999). However, some researches indicated that the spillover effects of FDI were weak, and the positive spillover effects of FDI should have some certain conditions (Young, 1992; Blomstrom, 1986; Haddad and Harrison, 1993; Kokko, 1994; DeMello, 1997; Aitken and Harrison, 1999). For many LDCs, there was no significant relationship between FDI and higher productivity growth in domestic firms, except for those countries having high-level human capital (Borensztein et al., 1998).

Whether FDI can bring positive spillover effects and stimulate technology progress in China is controversial. Chinese scholars also have different opinions. Jiang and Wang both investigated the enterprises invested by multinational companies (MNCs) in 2001 and 2003 respectively and after analyzing the collected data, they obtained contrary conclusions. According to the view of Jiang (2004), FDI can boost technology progress. There need not any precondition. MNCs will definitely bring their advanced technology, machinery and equipment to share Chinese markets and consequently enlarge their proportions. While Wang (2004) considered that the contribution of FDI to the endogenous technological capability was insignificant at the present stage. Learning capabilities and absorptive capacity of the local enterprises are key factors of spillover effects. Advanced machinery and equipment are not equal to technological capabilities. On the contrary, FDI enterprises would decrease and squeeze out R\&D activities in domestic enterprises.

Foreign direct investments are carried through by MNCs primarily. MNCs have obvious advantages compared to domestic firms, and possess of the most vigorous parts in the world economy. The contribution of FDI on technology transfer is obvious in theory. LDCs attract FDI, and then bring technology spillover effects through demonstration, imitation, reverse engineering, individual contact, diffusion of management skills. This is beneficial to shrink the gap in high-technology with developed countries and improve the technological inno- 
vation capabilities. However, the spillover effects cannot happen automatically; moreover, FDI may also bring negative spillover effects. Because of the stickiness of information (von Hipple, 1994), most technology and knowledge are tacit knowledge. Only through practice can they be mastered. The process and the extent to which spillovers occur were determined by both the owner of advanced technology (MNEs) and the receivers (local enterprises in the host countries) (Narula and Marin, 2003). The introduction of more advanced technology and the requirement of absorptive capability in the host country were twin factors of spillovers (Borensztein et al., 1998).

The purpose of this paper is to analyze quantitatively the relationship between FDI and regional innovation capability (RIC) and to find the determinants of RIC. We will empirically do research on the correlation between FDI and RIC using data of each province in China; verify whether more inward FDI in a province will lead to a higher level of innovation capability. We find that the spillover effects of FDI are not significant as it is usually thought. The impact of FDI on RIC is weak; the correlation between FDI and RIC is insignificant statistically. The regions which attract more FDI have not the higher RIC. The more of FDI will not necessarily bring the higher innovation spirits and entrepreneurial level. The research manifests that increasing domestic R\&D inputs, enhancing the stock of human capitals, improving the innovation capabilities and absorptive capacity in domestic enterprises are determinants to improve RIC.

The paper is organized as follows. Section 2 gives the concept of regional innovation capability. Section 3 researches empirically the relationship between FDI and RIC using multivariate statistical analysis. Section 4 constructs empirical model to analyze the impact of FDI on RIC further. Section 5 analyzes the effect of FDI to the level of entrepreneurship. Section 6 concludes.

\section{Regional Innovation Capability}

Technological innovation means the economic-technological activities including $\mathrm{R} \& \mathrm{D}$, production and commercial applications of new technology. Technological innovation is the activity which creates new economic value by means of new technology. The innovation capabilities will decide the long-term economic competitiveness in a region. The Research Group on Development and Strategy of Science and Technology of China (2002) considered RICs as the potentialities of producing streams of innovations related to commerce in a region. RICs refer to the capabilities of converting knowledge into new product, new process, and new service. RICs are not merely the science and technology competitiveness; their main character is the economic application of new technology. RICs are made

up of these factors: science and technology ( $S \& T$ ) human resource, the ability of knowledge fluxion that is the ability of making use of all kinds of resources in 
Table 1: Variables to measure RIC

\begin{tabular}{|c|c|c|}
\hline \multirow[t]{2}{*}{$\begin{array}{l}\text { The ability of } \\
\text { knowledge flux- } \\
\text { ion }\end{array}$} & $\begin{array}{l}\text { The ability of coop- } \\
\text { eration in science and } \\
\text { technology }\end{array}$ & $\begin{array}{l}\text { RFUND: The ratio of funds coming from enter- } \\
\text { prise to the total funds for } \mathrm{S} \& \mathrm{~T} \text { in institutions of } \\
\text { higher education and research institutions }\end{array}$ \\
\hline & $\begin{array}{l}\text { The ability of tech- } \\
\text { nology transfer }\end{array}$ & $\begin{array}{l}\text { FDI: Foreign direct investment } \\
\text { TVMARKET: Transaction value in technical } \\
\text { market } \\
\text { EXPIT: The average expenditure on import of } \\
\text { technology of each enterprise }\end{array}$ \\
\hline \multirow[t]{3}{*}{$\begin{array}{l}\text { Technological in- } \\
\text { novation capabili- } \\
\text { ties in enterprises }\end{array}$} & $\begin{array}{l}\text { The ability of } \mathrm{R} \& \mathrm{D} \\
\text { investments }\end{array}$ & $\begin{array}{l}\text { RR\&D: The ratio of R\&D investments in enter- } \\
\text { prises to the sales revenue } \\
\text { RS\&T: The ratio of enterprises having institutes } \\
\text { for S\&T to total large and medium-sized enter- } \\
\text { prises }\end{array}$ \\
\hline & The ability of design & $\begin{array}{l}\text { UTILITY: Number of utility models patent ap- } \\
\text { plications per } 10000 \text { population DESIGN: Num- } \\
\text { ber of designs patent applications per } 10000 \text { pop- } \\
\text { ulation }\end{array}$ \\
\hline & $\begin{array}{l}\text { The output of inno- } \\
\text { vation }\end{array}$ & $\begin{array}{l}\text { NEWSALES: The ratio of new products sales } \\
\text { revenue to total sales revenue } \\
\text { NEWRATE: The rate of output value of new } \\
\text { products }\end{array}$ \\
\hline \multirow[t]{2}{*}{$\begin{array}{l}\text { The innovation } \\
\text { environments }\end{array}$} & The calibers of labors & $\begin{array}{l}\text { COLLEGE: Number of college and higher level } \\
\text { per } 10000 \text { populations } \\
\text { HIGHEDU: Number of graduates from institu- } \\
\text { tions of higher education per } 10000 \text { populations } \\
\text { PEDUF: The educational funds per capita }\end{array}$ \\
\hline & S\&T human resource & $\begin{array}{l}\text { NS\&E: Number of scientists and engineers per } \\
10000 \text { populations }\end{array}$ \\
\hline \multicolumn{2}{|c|}{ The level of entrepreneurship } & $\begin{array}{l}\text { NPTE: Number of private technological enter- } \\
\text { prises }\end{array}$ \\
\hline \multicolumn{2}{|c|}{ The performance of innovations } & $\begin{array}{l}\text { PGDP: Gross domestic product per capita } \\
\text { LPRODUCT: Labor productivity of large and } \\
\text { medium-sized enterprises } \\
\text { INVENT: Number of invention patent applica- } \\
\text { tions per } 10000 \text { population }\end{array}$ \\
\hline
\end{tabular}

the world, the capabilities of technological innovation in enterprises, innovation environments and the economic performances of innovations. 


\section{Correlation Analysis between FDI and RIC}

\subsection{Indictors of RIC}

To evaluate the correlation between FDI and RIC, we need to describe RIC first, and establish a series of indictors to reflect RIC according to its meaning. The connotation of RIC is very abundant; the determinants include education, science and technology (S\&T) resources, the utilization of global knowledge, innovation capabilities in local enterprises, innovation environments and the regional policy. The series of indictors of RIC must reflect the present conditions accurately and objectively. We try to establish a series of indictors and all data can be obtained. Altogether we select 18 variables to measure RIC as listed in Table 1.

\subsection{Principle component analysis for the combined function evaluating RIC}

The data of above 18 variables are obtained from China Statistical Yearbook (2005), China High-tech Industry Statistical Yearbook (2004), and China Science and Technology Statistical Yearbook (2004). Some of the variables cannot be directly obtained and we proceed to some simple calculation. All data are the most up-to-date currently available.

Principal component analysis is a method for re-expressing multivariate data (Lattin et al., 2002). The first objective principal component seeks the linear combination of the original variables which has maximal variance so it can account for as much of the information as possible. We use the principal component analysis to obtain the combined function evaluating RIC of each province. Its excellence is that the coefficients are based on the correlation structure of the original variables from the data analysis; it does not have any influence of subjectivity. This is beneficial to analyze and appraise synthetically.

We analyzed the data of 30 provinces in China about above 18 variables with principal component analysis. Tibet is excluded in our analysis because most of the relevant data for it is either not available or zero. To avoid the influence of different metric units of each variable, we normalize the data first. So the analysis was based on the correlation matrix of variables.

We calculate eigenvalues of the correlation matrix and several larger eigenvalues are shown in Table 2 . 
Table 2: Eigenvalues

\begin{tabular}{cccc}
\hline Component & Eigenvalue & Proportion & Cumulative \\
\hline PCR1 & 9.7350 & 0.5408 & 0.5408 \\
PCR2 & 2.0352 & 0.1131 & 0.6539 \\
PCR3 & 1.7700 & 0.0983 & 0.7522 \\
PCR4 & 1.5061 & 0.0837 & 0.8359 \\
PCR5 & 1.0115 & 0.0562 & 0.8921 \\
\hline
\end{tabular}

Table 3: The first eigenvector and the loadings of eigenvector

\begin{tabular}{lcc}
\hline Variable & Eigenvector of the largest eigenvalue & Loadings \\
\hline RFUND & 0.1426 & 0.4448 \\
FDI & 0.1563 & 0.4875 \\
TVMARKET & 0.2811 & 0.8770 \\
EXPIT & 0.0851 & 0.2654 \\
RR\&D & 0.1485 & 0.4635 \\
RS\&T & 0.0776 & 0.2421 \\
UTILITY & 0.3123 & 0.9745 \\
DESIGN & 0.2574 & 0.8030 \\
NEWSALES & 0.1685 & 0.5256 \\
NEWRATE & 0.1917 & 0.5980 \\
COLLEGE & 0.2846 & 0.8879 \\
HIGHEDU & 0.2969 & 0.9264 \\
PEDUF & 0.3038 & 0.9478 \\
NS\&E & 0.2937 & 0.9164 \\
NPTE & 0.2309 & 0.7204 \\
PGDP & 0.2982 & 0.9304 \\
LPRODUCT & 0.1798 & 0.5610 \\
INVENT & 0.2996 & 0.9349 \\
\hline
\end{tabular}

The largest eigenvalue of the correlation matrix values 9.7350 and the first principal component can reflect $54.08 \%$ information of the original data. We select the first principal component (PCR1) to analyze further. The identity eigenvector of the largest eigenvalue and the factor loading of all original variables on the first principal component are shown in Table 3.

By the eigenvector of the largest eigenvalue in Table 3, we can get the expression of the first principal component (PCR1) as following:

$$
P C R 1=\sum_{i=1}^{18} \alpha_{i} y_{i},
$$


where $\alpha_{i}$ means each element of the eigenvector in Table 3 and $y_{i}$ means each original variable.

The expression shows PCR1 is the linear combination of each original variable and all coefficients are positive. Thus PCR 1 represents a synthetical grade of RIC. The region having stronger RIC will have larger score of PCR1. Moreover PCR1 can explain the majority of the information of all original data. So we use PCR1 as the synthetic evaluating function to appraise RIC. And the score of PCR1 of each province shows the actual conditions of RIC. We use PCR1 to represent RIC in the following analysis.

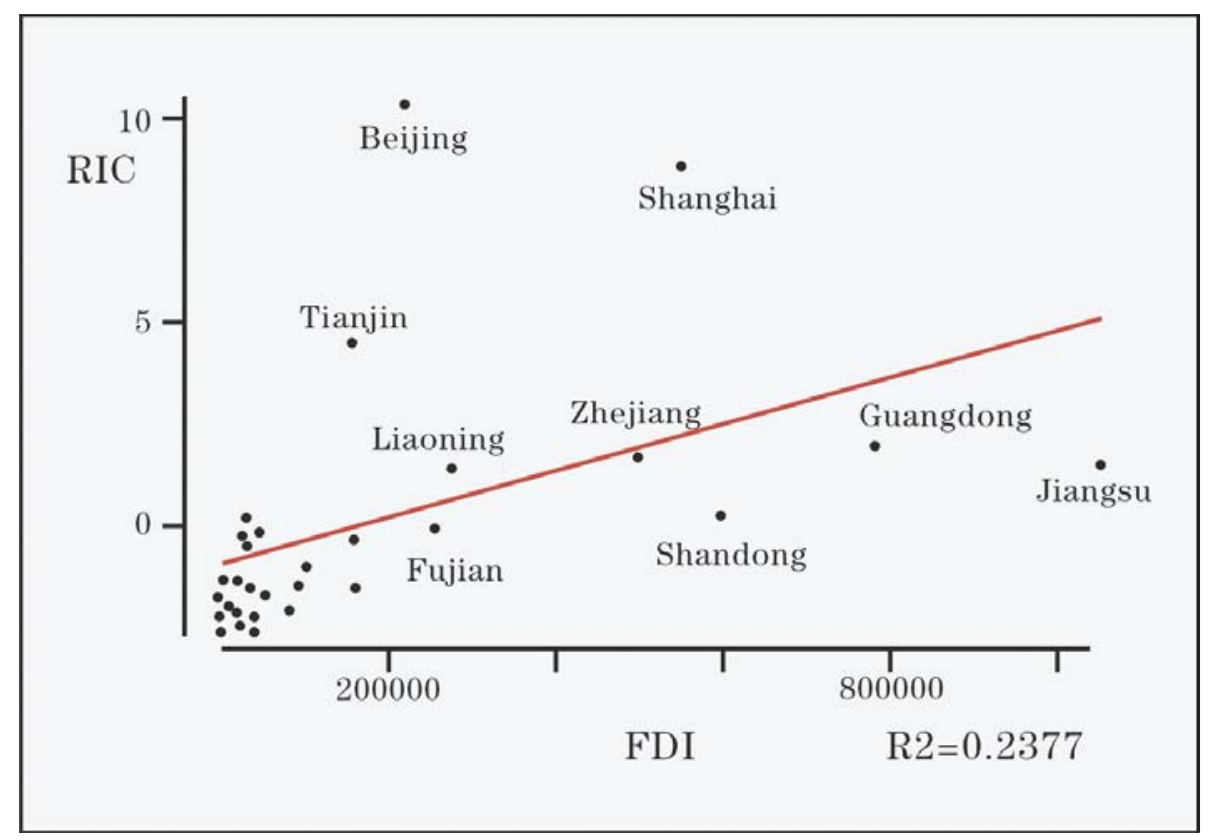

Figure 1: The scatter diagram of FDI and regional innovation capability

\subsection{Impact of FDI on RIC}

The loadings in Table 3 are the factor loadings of each original variable on PCR1. Factor loadings are the correlations between each original variable and the principal component (Lattin et al., 2003). The correlation coefficient between FDI and PCR1 is only $\mathbf{0 . 4 8 7 5}$. There is no significant correlation between FDI and RIC.

In Table 3 we can find that some loadings are relatively larger. High loadings mean high correlations. Variables having a high correlation with RIC include: 
TVMARKET (reflects the capability of technology transfer), UTILITY and DESIGN (reflect the capability of design in local enterprises), COLLEGE, HIGHEDU, PEDUF (reflect the caliber of employees), NS\&E (reflects S\&T human resource), NPTE (reflects the level of entrepreneurship) and PGDP, INVENT (reflect the performance of innovation). Therefore, for a nation or a region, the determinants of regional innovation capability include: attaching great importance to the inputs of S\&T, the ability of making full use of all kinds of S\&T resources including local special resources and global S\&T resources; technological innovation capabilities in local enterprises; having good environments beneficial to innovations; and the outstanding performance of local economic, which become the powerful pull force of innovation.

We draw the scatter diagram of FDI and RIC to show the correlation obviously. RIC is represented by the score of the first principal component above. The scattergram shows the distribution of the regions. We also perform regression analysis and obtain the regression curve. See Figure 1.

We can observe the relationship between FDI and RIC clearly by Figure 1. From the scatter of points that represent each region in Figure 1, we can discover that there are many points far away from the regression curve, such as Beijing, Shanghai, Tianjin and Jiangsu. The determinate coefficient $R^{2}$ is only 0.2377 ; it indicates that FDI can only explain $23.77 \%$ of the variation of RIC.

In Figure 1, we can also find that there are a lot of points almost gathered together. These points represent the provinces in which both FDI and RIC are all lagged behind. These provinces are located in the central or western region of China, are less developed in economy because of the lagged notion, policy and geographic location. The behindhand innovation capabilities are mainly induced by the lagged economic conditions. To eliminate the influence of economic development, we calculate the correlation again canceling the regions in which both FDI and RIC are all lagged behind and obtain the correlation coefficient is minus 0.2925. This indicates that FDI has a negative effect on RIC. Inward FDI might have the crowding-out effect on innovation and domestic R\&D activity. Because MNEs possess superior technological assets and management skills over domestic firms, their entries monopolize the original competition market in the host country, crowd out the domestic firms in the industry and lower the market share of domestic firms. As noted by Aitken and Harrison (1999), an increased competition associated with foreign presence might reduce the productivity of domestic firms. Purchasing technologies from abroad is a substitute for innovating on one's own (Cheung and Lin, 2004). This substitute is more attractive when conducting one's own R\&D is risky. Domestic firms may fall into a recurrence of "laggard, introduce foreign technologies, laggard again and introduce again" without enough absorptive capacity. MNEs invest and incorporate with 
local firms, which may cause the innovation activities in local firms be decreased, be transferred or be closed. Thus decrease the regional $\mathrm{R} \& \mathrm{D}$ activities, make domestic firms excessively rely on foreign technologies. This further handicaps the innovation and technological progress in domestic firms.

Jiangsu and Guangdong attracted inward FDI the most. The amount of FDI in Jiangsu is 10.56 billions dollars in 2003, and 7.82 billions dollars in Guangdong. The amount preponderated over other regions greatly. But their regional innovation capabilities located in the sixth and the fourth respectively, and have great difference with the former. Then we compare each original variable carefully and discover that on three variables that reflect the caliber of employees, which are number of college and higher level per 10000 populations (COLLEGE), number of graduates from institutions of higher education per 10000 populations (HIGHEDU), the educational funds per capita (PEEDUF), Guangdong located 18, 16 and 21 respectively in the whole country. Variable that reflects the human resource in $\mathrm{S} \& \mathrm{~T}$, number of scientists and engineers per 10000 populations (NS\&E), Guangdong located 7. And Jiangsu located 20, 6, 6 and 4 on above variables respectively. These indicate that the level of human capital does not match the amount of FDI in Guangdong and Jiangsu. Whether the stock of human capital is high or low will decide the spillover effects directly and influence a nation's indigenous innovation capabilities and potentiality directly. Only when the volume of FDI matches the stock of human capital and technological capabilities can the RIC be developed and enhanced.

The region with the strongest RIC is Beijing, followed by Shanghai, while FDI in these two regions located in the eighth and the fourth respectively. What drives the innovation capability in Beijing and Shanghai? Obviously we cannot get the reasonable explain only from FDI. The superiority in Beijing includes the abundant science and technology ( $\& \& \mathrm{~T}$ ) resources, strong capability of creating new knowledge, attaching importance to S\&T inputs, the most excellent employees, and the good environments for i nnovation. While in Shanghai, there is a good foundation for industrial innovation; capabilities of indigenous innovation in local enterprises keep ahead; and there hold strong financial strength and powerful capital advantage. Zhejiang is a province where the private economy developed quite well and the capability of innovation in private enterprise is extraordinary. Zhejiang developed quickly because of the dual superiorities of S\&T resources and the system. People have great enthusiasm to start-up. There have perfect mechanism for indigenous innovation, investment and financing and fostering talented person in Zhejiang. Zhejiang is an apotheosis of making full use of local resources to improve RIC.

Therefore, attracting FDI is not the unique means to increase RIC, and it is not an important means either. The determinants of RIC include domestic 
R\&D inputs, the original driving force of innovation, the ability of making full use of local special resources and global S\&T resources, the good environments beneficial to innovation. Besides above factors, the local economic condition is the strong pull force for innovation.

\section{Empirical Model about the Effect of FDI on the Innovation Capa- bility}

We measure the innovation capability with various different variables and use principal component analysis to obtain combined function to represent RIC synthetically in above analysis. PCR 1 can explain RIC well but it can not reflect the degree of innovativeness concerned. So PCR1 is no longer suited for analyzing the effect of FDI on different degrees of innovativeness. Scholars often use patent data to measure the technological innovation. Using patent data as a measure of technological innovation has several limitations. First, it is possible that some innovators in China may not file patent applications. They may have chosen to keep their innovation as "technology secrets" instead so as to prevent information leakage from filing patent applications. Second, some patents may have never been commercialized and thus can not be considered as an innovation. As the developing of the notion about intellectual property in Chinese firms the first limitation has been ameliorated greatly. Alternatively, we can use other measures such as new product sales. But one problem with using this alternative measure is that there may be a potentially large distortion in the official statistics in China. Because Chinese government provides tax benefits to new products sales as an incentive to stimulate $R \& D$, it is likely that firms may misreport information about new product sales to gain tax benefits. Another drawback of using new products sales is that it does not include process innovations that improve the manufacture technology for existing products. Patent data can include both product and process innovations. When an inventor applies for a patent to the patent office, this is usually the potential sign of economic value of innovation and representation of the innovation capability. Furthermore, the patent data are complete, accurate and can be obtained easily. Thus, we use the number of patent applications in China to measure the regional innovation capabilities.

In less than 20 years, China has made tremendous progress in establishing a legal system for the protection of innovation. China's first patent law was enacted in 1984 and came into effect in 1985. Since then, the law has been amended twice. Since the passage of the 1984 patent law, the central government has issued over 20 regulations and guidelines so as to promote innovation activity in China. Today's patent law in China is pretty much in line with the international standard (Cheung and Lin, 2004).

The patent law of China classifies patents into three categories: invention, 
utility model, and external design. The invention patent refers to the new technoproject put forward on the product, method or its modification, which can form the products having indigenous intellectual property. The utility model patent means the new practical techno-project put forward on the shape, structure of the products or their combinations. The external design patent is the new design which is full of pleasant impressions and is suited for the application in industry about the shape, pattern, color, or their combinations of the products. Among three types of patents the invention patents are regarded as major innovations, they can represent the technological capabilities mostly.

We use the following model to estimate the spillover effects of FDI on innovation capabilities in China. Spillover effects refer to the indirect effects generated by the presence of foreign firms and obtain technology progress in the host country and performance improvement in local firms.

Patent $=\beta_{0}+\beta_{1}$ FDI $+\beta_{2}$ PGDG $+\beta_{3}$ S\&TEXP $+\epsilon$

Table 4: Effects of FDI on domestic patent applications

\begin{tabular}{lcccc}
\hline & Invention & Utility model & External design & Total patent \\
\hline Constant & -0.1442 & 3.6615 & 0.1786 & 2.3783 \\
& $(-0.1015)$ & $(2.1761)^{2}$ & $(0.0763)$ & $(1.5452)$ \\
FDI & 0.1147 & 0.1620 & 0.3950 & 0.2139 \\
& $(1.6289)$ & $(1.9440)^{1}$ & $(3.4054)^{3}$ & $(2.8055)^{4}$ \\
PGDP & 0.2907 & -0.1437 & -0.0058 & 0.0544 \\
& $(1.5764)$ & $(-0.6583)$ & $(-0.0191)$ & $(0.2721)$ \\
S\&TEXP & 0.7560 & 0.8448 & 0.6485 & 0.7704 \\
& $(7.4040)^{4}$ & $(6.9869)^{4}$ & $(3.8538)^{4}$ & $(6.9652)^{4}$ \\
\hline
\end{tabular}

Dependent variable is the number of patent applications. All variables are in logarithm. Figures in parentheses are $t$ statistics. ${ }^{1}$ Significant at the 0.1 level. ${ }^{2}$ Significant at the 0.05 level. ${ }^{3}$ Significant at the 0.01 level. ${ }^{4}$ Significant at the 0.001 level.

We use the number of patent applications (Patent) as a measure of innovation capability. FDI refers to the realized values of FDI lagged one year considering that FDI inflow to China impacts on domestic innovations within a short period of time. As measures of input to R\&D activity, we use expenditures on science and technology development (S\&TEXP) and exclude the number of R\&D personnel to avoid the colinearity. Finally, considering the fact that different provinces are at different stage of economic development so that their innovation capabilities should also differ, we include the level of per capita GDP (PGDP) in our estimation. Where $\beta_{0}$ is the estimated intercept of the equation and $\epsilon$ is the error 
term. The coefficients measure magnitude of the influence of FDI, PGDP and S\&TEXP respectively. The data are taken from China Statistical Yearbook and China Technology Statistical Yearbook, covering 30 provinces. Tibet is excluded in our analysis because most of the relevant data for it is either not available or zero.

We estimate the equation with the ordinary least squares (OLS). And dependent variables are each type of patent (invention, utility model, and design) as well as the total patent applications.

In Table 4, the determinate coefficients $R^{2}$ of four models are all above 0.84 , and the values of $\mathrm{F}$ are significant at the level of 0.0001 . This shows that four models all have great statistical significance and they can explain the variations of all types of patent applications more than 84 percent. For the number of invention patent applications, the coefficient of FDI is positive, but it is statistically insignificant even under the level of 0.10. So FDI has no significant effect to the number of applications for invention patents. There has positive effect for FDI to the number of utility model patents, and has significant positive effect to the design patents and total patents. It is reasonable because invention patents in general are the most complicated and the advanced technology cannot be transferred from inward FDI automatically. Design patents are the least sophisticated

so that spillover effects are more likely existed through "demonstration effect" of FDI mentioned earlier.

As can been seen by Table 4, S\&TEXP has significant effect to the number of all three types of patents and the total patents under the significant level of 0.001. The results manifest that S\&TEXP is the most important factor to increase the innovation capabilities. FDI has positive influence to some extent, but has no significant effect to increase creative inventions and the inventions having indigenous intellectual property.

\section{Effect of FDI on the Level of Entrepreneurship}

We use the number of private technology enterprises (NPTE) as a measure of entrepreneurial levels. FDI refers to the realized values of FDI lagged one year considering that FDI inflow to China impacts on innovation activities within a short period of time.

We draw the scatter plot of FDI and NPTE to show the correlation clearly. The scatter plot shows the distribution of the regions and it can manifest the effect of FDI on the entrepreneurial level. 


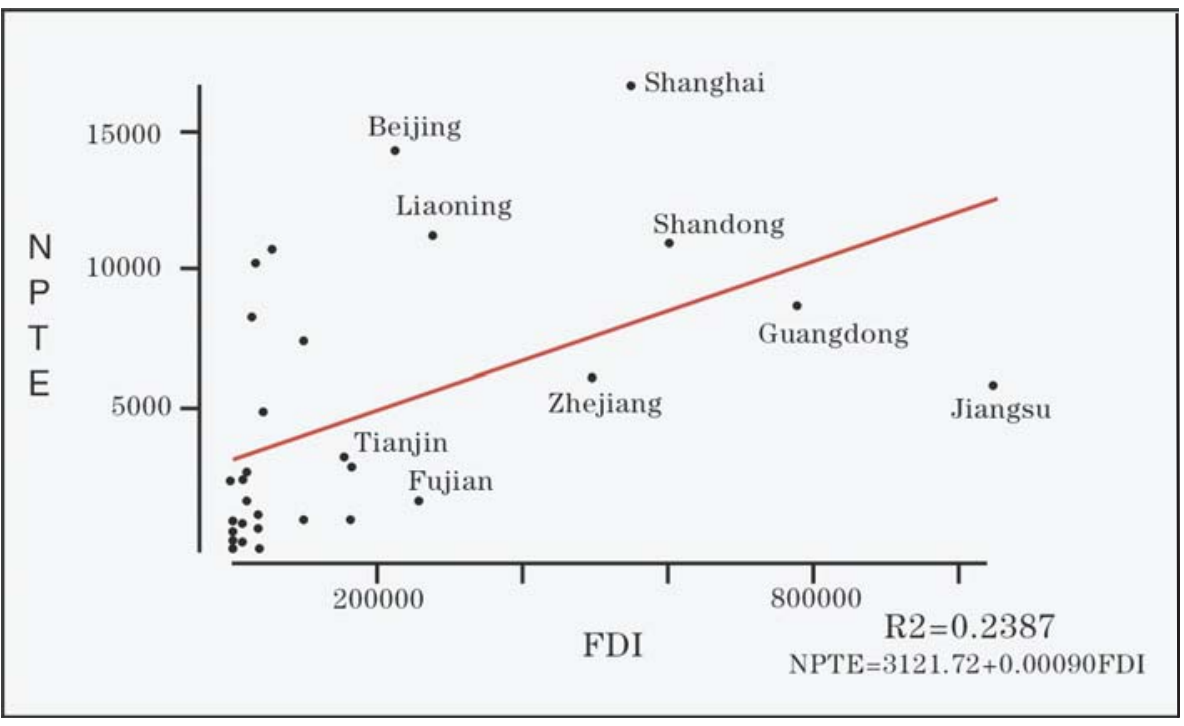

Figure 2: The scatter plot of FDI and the number of private technological enterprises

We observe the scatter plot in which each point represents one province and find that there are many points far away from the regression curve. The correlation coefficient between NPTE and FDI is only 0.4885 and is insignificant statistically. The determinate coefficient $R^{2}$ is 0.2387 and this indicates that FDI can only explain $23.87 \%$ of the variation of NPTE. So we can make a conclusion that FDI has no direct significant effect to the level of entrepreneurship. The more of FDI will not bring the higher entrepreneurial level.

The result may be induced by the crowing-out effect of FDI. Because of the high risk to establish an enterprise, a successful entrepreneur must be an adventurous pioneer daring to take the tremendous risk and failure. The presence of foreign enterprises may provide higher wage for employees and increase the competition in the market which increases the difficulty of successfully building an enterprise. So it is likely that many people having no enough entrepreneur spirits would rather select a secure and steady job in foreign enterprises than undertake the risk to carve out.

\section{Conclusions and policy implications}

As far as LDCs are concerned, introducing in advanced technology is a shortcut to facilitate technology progress. FDI has been regarded as an important channel for technology diffusion. However, the results in this paper demonstrate as follows.

First, the correlation between FDI and RIC is insignificant statistically. The 
impact of FDI on RIC is inappreciable. The regions which attract more FDI have not the higher RIC. Only when the volume of FDI matches the stock of human capital and technological capabilities can the RIC be developed and enhanced. This finding is the same to the view of Borensztein (1998). Attracting FDI is not the unique means to increase RIC, and it is not an important means either. Sometimes inward FDI might have the crowding-out effect on innovation and domestic R\&D activity. The determinants to improve RIC include such factors: increasing domestic R\&D inputs, intensifying the stock of human capitals, improving absorptive capacity in domestic firms and having good environments for innovations.

Second, the results of the statistical model indicate that investment in R\&D activities is the most important factor to enhance the innovation capabilities. FDI has positive spillover effects to some extent, but has no significant effect to increase creative inventions and indigenous innovation capabilities.

Third, FDI has no direct significant effect to the level of entrepreneurship. The more of FDI will not necessarily bring the higher innovation spirits and entrepreneurial level.

To sum up above results, the inward FDI will facilitate technology progress and improve RIC to some degree. But we cannot think blindly that we introduce in FDI the more the better. The advanced technology and equipments of FDI cannot be transferred to domestic firms automatically. So we can barely rely on FDI to improve RIC. Based on above analysis we put forward some policy implications as follows, which may also be effective to other LDCs. Firstly, it is urgent for China to improve the stock of human capital and indigenous R\&D capabilities. Whether the stock of human capital is high or low will decide the spillover effects directly, and influence a nation's indigenous innovation capabilities and potentiality. It is necessary for China to increase inputs in fostering human capitals and to promote the indigenous R\&D capabilities. These are important to shrink the technology gap between domestic firms and foreign capital enterprises. Only when the host country has enough technological talented persons, can MNCs arrange R\&D projects in the host country and train the native high technological talented persons, thus increase the spillover effects of FDI. Secondly, Chinese government should focus on the quality of inward FDI and insist on the sticking point to advance indigenous innovation capabilities. Try to urge and guide FDI to be on the trajectory which is beneficial to improve our indigenous innovation capabilities. Thirdly, China should try to create a fair competition environment for domestic firms to compete with foreign enterprises, and keep sufficient competitive pressure. Under the intense competition environments it may force MNCs to transfer more advanced technology to our country. 


\section{Appendix}

Table A: The original data of indices reflecting RIC

\begin{tabular}{lrrrrrr}
\hline Region & RFUND & FDI & TVMARKET & EXPIT & RR\&D & RS\&T \\
& $(\%)$ & $(\$ 10000)$ & $(10000$ yuan $)$ & $(1000$ yuan $)$ & $(\%)$ & $(\%)$ \\
\hline Beijing & 11.292 & 219126 & 4249975 & 67.456 & 1.48 & 5.4 \\
Tianjin & 17.110 & 153473 & 450276 & 282.432 & 0.52 & 3.6 \\
Hebei & 12.432 & 96405 & 72718 & 87.597 & 0.44 & 3.4 \\
Shanxi & 8.835 & 21361 & 59960 & 114.117 & 0.48 & 3.3 \\
Mongolia & 5.713 & 8854 & 104085 & 129.122 & 0.36 & 3.4 \\
Liaoning & 20.398 & 282410 & 752817 & 209.176 & 1.11 & 5.4 \\
Jilin & 12.240 & 19059 & 107900 & 209.201 & 0.30 & 2.7 \\
Heilongjiang & 13.941 & 32180 & 125715 & 271.900 & 0.70 & 4.7 \\
Shanghai & 21.594 & 546849 & 1716963 & 495.246 & 0.76 & 5.7 \\
Jiangsu & 20.604 & 1056365 & 897855 & 238.035 & 0.68 & 5.9 \\
Zhejiang & 32.077 & 498055 & 581465 & 211.439 & 0.56 & 4.4 \\
Anhui & 10.178 & 36720 & 90675 & 692.454 & 0.64 & 4.3 \\
Fujian & 18.382 & 259903 & 141395 & 125.292 & 0.76 & 3.0 \\
Jiangxi & 11.927 & 161202 & 93661 & 145.457 & 1.05 & 6.5 \\
Shandong & 12.077 & 601617 & 750850 & 78.887 & 0.80 & 3.9 \\
Henan & 13.252 & 53903 & 203207 & 87.646 & 0.53 & 4.0 \\
Hubei & 24.124 & 156886 & 461700 & 185.117 & 0.69 & 5.5 \\
Hunan & 22.791 & 101835 & 408280 & 161.274 & 0.74 & 6.0 \\
Guangdong & 17.452 & 782294 & 572651 & 92.784 & 0.90 & 3.4 \\
Guangxi & 9.329 & 41856 & 90955 & 100.997 & 0.75 & 5.0 \\
Hainan & 0.605 & 42125 & 1885 & 6.326 & 0.30 & 1.6 \\
Chongqing & 23.712 & 26083 & 596186 & 140.147 & 0.81 & 5.6 \\
Sichuan & 8.309 & 41231 & 165640 & 192.588 & 0.88 & 6.7 \\
Guizhou & 2.867 & 4521 & 13533 & 81.887 & 0.72 & 4.2 \\
Yunnan & 6.772 & 8384 & 215555 & 159.391 & 0.33 & 2.7 \\
Shanxi & 13.454 & 33190 & 139129 & 174.977 & 1.68 & 8.0 \\
Gansu & 8.772 & 2342 & 119608 & 144.667 & 0.48 & 6.5 \\
Qinghai & 0.389 & 2522 & 12793 & 21.509 & 0.64 & 3.7 \\
Ningxia & 2.589 & 1743 & 12827 & 52.367 & 0.44 & 2.1 \\
Xinjiang & 8.172 & 1534 & 133371 & 215.563 & 0.20 & 3.4 \\
\hline & & & & & &
\end{tabular}


Table A: The original data of indices reflecting RIC (continued)

\begin{tabular}{|c|c|c|c|c|c|c|}
\hline Region & $(2)$ & (3) & (4) & (5) & (6) & (7) \\
\hline Beijing & 4.28 & 2.35 & 19.87 & 26.3 & 2389.04 & 67.90 \\
\hline Tianjin & 3.08 & 1.22 & 27.10 & 28.3 & 1433.85 & 50.77 \\
\hline Hebei & 0.47 & 0.20 & 5.20 & 5.8 & 589.41 & 21.08 \\
\hline Shanxi & 0.30 & 0.10 & 6.50 & 7.1 & 522.96 & 15.37 \\
\hline Mongolia & 0.29 & 0.19 & 10.70 & 11.0 & 663.30 & 13.04 \\
\hline Liaoning & 1.77 & 1.01 & 14.00 & 15.6 & 828.75 & 27.50 \\
\hline Jilin & 0.72 & 0.24 & 2.80 & 3.4 & 684.69 & 24.02 \\
\hline Heilongjiang & 0.76 & 0.17 & 5.80 & 6.1 & 467.70 & 22.26 \\
\hline Shanghai & 3.55 & 4.40 & 28.00 & 30.6 & 1849.6 & 51.34 \\
\hline Jiangsu & 1.26 & 1.30 & 14.70 & 15.6 & 492.23 & 26.60 \\
\hline Zhejiang & 1.28 & 2.70 & 15.40 & 16.4 & 747.45 & 21.94 \\
\hline Anhui & 0.24 & 0.10 & 8.80 & 9.3 & 442.84 & 13.74 \\
\hline Fujian & 0.72 & 1.17 & 27.80 & 26.9 & 456.06 & 15.09 \\
\hline Jiangxi & 0.26 & 0.20 & 11.70 & 12.4 & 467.31 & 15.31 \\
\hline Shandong & 1.02 & 0.63 & 13.10 & 14.3 & 548.61 & 18.24 \\
\hline Henan & 0.35 & 0.17 & 7.20 & 8.4 & 442.08 & 13.85 \\
\hline Hubei & 0.65 & 0.38 & 13.30 & 15.2 & 578.28 & 23.83 \\
\hline Hunan & 0.49 & 0.39 & 12.10 & 12.4 & 522.01 & 16.61 \\
\hline Guangdong & 1.80 & 3.61 & 14.60 & 15.6 & 518.52 & 15.40 \\
\hline Guangxi & 0.22 & 0.12 & 20.70 & 21.4 & 518.40 & 10.31 \\
\hline Hainan & 0.16 & 0.12 & 31.90 & 32.9 & 521.37 & 9.64 \\
\hline Chongqing & 0.61 & 0.86 & 29.30 & 31.5 & 364.29 & 16.18 \\
\hline Sichuan & 0.31 & 0.32 & 15.80 & 16.8 & 361.74 & 11.59 \\
\hline Guizhou & 0.19 & 0.06 & 7.40 & 8.9 & 447.42 & 7.99 \\
\hline Yunnan & 0.18 & 0.13 & 3.00 & 3.6 & 383.84 & 7.92 \\
\hline Shanxi & 0.42 & 0.14 & 11.20 & 13.0 & 723.09 & 30.01 \\
\hline Gansu & 0.18 & 0.03 & 2.40 & 2.2 & 567.02 & 15.08 \\
\hline Qinghai & 0.08 & 0.05 & 2.50 & 2.6 & 450.65 & 10.81 \\
\hline Ningxia & 0.31 & 0.21 & 4.70 & 5.9 & 716.36 & 12.85 \\
\hline Xinjiang & 0.44 & 0.17 & 1.10 & 1.1 & 989.43 & 15.48 \\
\hline
\end{tabular}

(2): Utility (item/1000 persons), (3) Design (item/10000 persons), (4) Newsales (\%), (5) Newrate (\%), (6) College (persons/10000 persons), (7) High education (person/10000 persons) 
Table A: The original data of indices reflecting RIC (continued)

\begin{tabular}{lrrrrrl}
\hline Region & $(8)$ & $(9)$ & $(10)$ & $(11)$ & $(12)$ & $(13)$ \\
\hline Beijing & 2664.48 & 153.451 & 14628 & 37058 & 124840 & 5.83 \\
Tianjin & 1099.34 & 54.646 & 3306 & 31550 & 129604 & 3.94 \\
Hebei & 341.73 & 11.574 & 7626 & 12918 & 76864 & 0.14 \\
Shanxi & 392.47 & 16.563 & 2645 & 9150 & 56938 & 0.17 \\
Mongolia & 392.87 & 9.425 & 885 & 11305 & 75935 & 0.12 \\
Liaoning & 535.53 & 27.777 & 11513 & 16297 & 82833 & 0.68 \\
Jilin & 491.37 & 18.477 & 1720 & 10932 & 98580 & 0.38 \\
Heilongjiang & 493.30 & 17.437 & 8496 & 13897 & 126224 & 0.34 \\
Shanghai & 1778.28 & 71.390 & 16960 & 55307 & 180766 & 3.90 \\
Jiangsu & 627.25 & 28.159 & 6074 & 20705 & 103807 & 0.59 \\
Zhejiang & 875.69 & 26.245 & 6358 & 23942 & 85096 & 0.76 \\
Anhui & 285.13 & 8.804 & 5013 & 7768 & 74493 & 0.10 \\
Fujian & 561.73 & 14.072 & 1718 & 17218 & 92445 & 0.24 \\
Jiangxi & 316.20 & 8.669 & 1057 & 8189 & 59442 & 0.15 \\
Shandong & 408.72 & 17.769 & 11066 & 16925 & 87702 & 0.35 \\
Henan & 262.58 & 9.657 & 11022 & 9470 & 55154 & 0.12 \\
Hubei & 420.66 & 23.866 & 3055 & 10500 & 79099 & 0.27 \\
Hunan & 352.46 & 10.177 & 1016 & 9117 & 77373 & 0.25 \\
Guangdong & 765.50 & 24.432 & 8902 & 19707 & 100561 & 0.99 \\
Guangxi & 295.05 & 6.647 & 735 & 7196 & 74789 & 0.10 \\
Hainan & 404.16 & 3.148 & 110 & 9450 & 104768 & 0.16 \\
Chongqing & 386.38 & 15.457 & 762 & 9608 & 66436 & 0.17 \\
Sichuan & 305.59 & 12.878 & 1289 & 8113 & 67120 & 0.18 \\
Guizhou & 245.44 & 5.045 & 424 & 4215 & 69320 & 0.11 \\
Yunnan & 329.53 & 7.499 & 2585 & 6733 & 152411 & 0.16 \\
Shanxi & 502.88 & 23.447 & 10522 & 7757 & 72950 & 0.29 \\
Gansu & 350.19 & 16.381 & 779 & 5970 & 66038 & 0.12 \\
Qinghai & 371.98 & 10.958 & 42 & 8606 & 81148 & 0.09 \\
Ningxia & 419.11 & 11.524 & 93 & 7880 & 51701 & 0.15 \\
Xinjiang & 605.30 & 8.658 & 952 & 11199 & 159515 & 0.13 \\
\hline
\end{tabular}

(8) PEDUF (yuan/year), (9) NS\&E (person/10000 persons), (10) NPTE (unit), (11) PGDP (yuan/person), (12) LPRDUCT (yuan/person-year), (13) Invent (item/10000 persons) 
Table B: The data for regression (section 4 in the paper)

\begin{tabular}{lrrrrrrr}
\hline Region & $(1)$ & $(2)$ & $(3)$ & $(4)$ & $(5)$ & $(6)$ & $(7)$ \\
\hline Beijian & 8608 & 6321 & 3473 & 18402 & 219126 & 37058 & 436.570 \\
Tianjin & 4013 & 3142 & 1251 & 8406 & 153473 & 31550 & 83.721 \\
Hebei & 979 & 3258 & 1410 & 5647 & 96405 & 12918 & 74.294 \\
Shanxi & 571 & 1013 & 365 & 1949 & 21361 & 9150 & 44.693 \\
Mongolia & 286 & 699 & 472 & 1457 & 8854 & 11305 & 18.334 \\
Liaoning & 2907 & 7494 & 4294 & 14695 & 282410 & 16297 & 145.243 \\
Jilin & 1048 & 1951 & 658 & 3657 & 19059 & 10932 & 51.312 \\
Heilongjiang & 1325 & 2932 & 662 & 4919 & 32180 & 13897 & 60.095 \\
Shanghai & 6737 & 6131 & 7603 & 20471 & 546849 & 55307 & 288.442 \\
Jiangsu & 4423 & 9405 & 9704 & 23532 & 1056365 & 20705 & 338.022 \\
Zhejiang & 3578 & 6021 & 12695 & 25294 & 498055 & 23942 & 176.667 \\
Anhui & 658 & 1597 & 688 & 2943 & 36720 & 7768 & 83.471 \\
Fujian & 850 & 2524 & 4124 & 7498 & 259903 & 17218 & 69.227 \\
Jiangxi & 663 & 1152 & 870 & 2685 & 161202 & 8189 & 32.434 \\
Shandong & 3230 & 9358 & 5773 & 18388 & 601617 & 16925 & 222.487 \\
Henan & 1213 & 3448 & 1657 & 6318 & 53903 & 9470 & 75.030 \\
Hubei & 1674 & 3953 & 2333 & 7960 & 156886 & 10500 & 108.126 \\
Hunan & 1734 & 3301 & 2658 & 7693 & 101835 & 9117 & 71.549 \\
Guangdong & 8093 & 14682 & 29426 & 52201 & 782294 & 19707 & 332.398 \\
Guangxi & 495 & 1114 & 593 & 2202 & 41856 & 7196 & 34.809 \\
Hainan & 137 & 135 & 103 & 375 & 42125 & 9450 & 3.258 \\
Chongqing & 562 & 1910 & 2699 & 5171 & 26083 & 9608 & 44.476 \\
Sichuan & 1638 & 2775 & 2847 & 7260 & 41231 & 8113 & 154.312 \\
Guizhou & 450 & 765 & 271 & 1486 & 4521 & 4215 & 15.478 \\
Yunnan & 740 & 793 & 599 & 2132 & 8384 & 6733 & 25.577 \\
Shanxi & 1099 & 1587 & 531 & 3217 & 33190 & 7757 & 114.387 \\
Gansu & 334 & 483 & 93 & 910 & 2342 & 5970 & 26.561 \\
Qinghai & 49 & 44 & 31 & 124 & 2522 & 8606 & 6.686 \\
Ningxia & 89 & 184 & 126 & 399 & 1743 & 7880 & 6.312 \\
Xinjiang & 272 & 870 & 350 & 1492 & 1534 & 11199 & 17.399 \\
\hline & & & & & & &
\end{tabular}

(1)INVENT (item), (2) UTILITY (item), (3) DESIGN (item), (4) PATENT (item), (5) FDI (10000\$), (6) PGDP (yuan/person), (7) STEXP (100 million yuan).

All data are obtained from China Statistical Yearbook (2005), China Hightech Industry Statistical Yearbook (2004), and China Science and Technology Statistical Yearbook (2004). Some of the variables cannot be directly obtained and we proceed to some simple computation. 


\section{References}

Aitken, B. and Harrison A., (1999). Do domestic firms benefit from foreign investment? Evidence from Venezuela. Amercian Economic Review 89, 605-618.

Blomstrom, M and Persson, H, (1983). Foreign investment and spillover efficiency in an underdeveloped economy: Evidence from the Mexican manufacturing industry. World Development 11, 493-501.

Blomstrom, M. (1986). Foreign investment and productive efficiency: The case of Mexico. Journal of Industrial Economics 15, 97-110.

Blomstrom, M. and Wolff, E. N. (1989). Multinational corporations and productivity convergence in Mexico. National Bureau of Economic Research Working Paper, No. 3141. Cambridge, Massachusetts.

Borensztein, E., De Gregorio J., and Lee J-W. (1998). How does foreign investment affect economic growth? Journal of International Economics 45,115-135.

Caves, R. E., (1974), Multinationational firms, competition and productivity in host country markets. Economica 41, 176-193.

Cheung, K. Y. and Lin, P., (2004). Spillover effects of fdi on innovation in China: Evidence from the provincial data. China Economic Review 15, 25-44.

DeMello, Luiz, R. Jr. (1997). Foreign direct investment in developing countries and growth: A selective survey. The Journal of Development Studies 34, 1-34.

Globeman, S. (1979). Foreign direct investment and spillovers efficiency benefits in Canadian manufacturing industries. Canadian Journal of Economics 12, 42-56.

Haddad, M. and Harrison, A. (1993). Are there positive spillovers from direct foreign investment? Journal of Development Economics 42, 51-74.

Imbriani, C., and Reganati, F. (1997). International efficiency spillovers into the Italian manufacturing sector (English summary). Economia Internazionale 50, 583-595.

Jiang, X. J. (2004). Impact of inward FDI on technology progress in Chinese industry and R\&D capability advance. International Economic Review 2, 13-18.

Kokko, A. (1994). Technology market characteristics and spillovers. Journal of Development Economics 43, 279-293.

Kokko A., Tansini, R. and Zejan, M. (1996). Local technological capability and productivity spillovers from FDI in the Uruguayan manufacturing sector. Journal of Development Studies 32, 602-611.

Lattin, J. M., Carroll, J. D. and Green, P. E. (2002). Analyzing Multivariate Data Thomson Learning Press.

Nadiri, I. M. (1993). Innovations and technological spillovers. National Bureau of Economic Research Working Paper, No. 4423. Cambridge, Massachusetts. 
Narula, R. and Marin, A., (2003). FDI spillovers, absorptive capacities and human capital development: Evidence from Argentina. MERIT (Maastricht Economic Research Institute on Innovation and Technology) Research Memorandum series, 16.

National Bureau of Statistic of China (2005). China Statistical Yearbook. China Statistics Press.

National Bureau of Statistic of China (2004) China High-tech Industry Statistical Yearbook. China Statistics Press.

National Bureau of Statistic of China (2004). China Science and Technology Statistical Yearbook. China Statistics Press.

Research Group on Development and Strategy of Science and Technology of China (2002). Annual Report of Regional Innovation Capability of China. Economic Management Publishing House.

Sjoholm, F. (1999). Productivity growth in Indonesia: The role of regional characteristics and foreign direct investment. Economic Development and Cultural Change 47, 559-584.

von Hopple, E. (1994). "Sticky information" and the locus of problem solving: Implications for innovation. Management Science 40, 429-439.

Wang, C. F., (2004). FDI and fostering of endogenous technological capability. International Economic Review 2, 19-22.

Young, A. (1992). A tale of two cities: Factor accumulation and technology change in Hong Kong and Singapore. NBER (National Bureau of Economic Research) Macroeconomics Annual, MIT Press.

Received July 19, 2005; accepted September 16, 2006.

Yufen Chen

College of Statistics aand Mathematics

Zhejiang Gongshang University

Hangzhou, 310035, China

cyf1688@sohu.com and cyf1688@126.com 